\title{
An Evaluation of the Problems Encountered by Elementary School Students While Using Internet
}

\author{
https://doi.org/10.3991/ijet.v14i22.11731 \\ Aykut Yasakcı $(\bowtie)$ \\ Near East University, Nicosia, North Cyprus \\ aykut.yasakci@neu.edu.tr \\ Hasan Özdal \\ Final International University, Kyrenia, North Cyprus
}

\begin{abstract}
Today, as a result of the development of technology and the resulting innovations, it can be seen that internet applications and software are widely used by large masses starting from very small age groups to adults by means of computers and mobile devices. This wide and popular usage presents several living opportunities to its users but it also brings to fore the question "how effective and accurate are we using internet and its applications?" The state of awareness of children as regards "accurate and conscious internet usage" who particularly widely use products such as computers and mobile devices appears as an important research question. In light of this information, the purpose of the research is to determine the problems faced by 5 th grade students while using the internet. The Interview technique which is a qualitative method is used in the study and the sample group consists of 5th grade students (103 pupils) who study at a private elementary school in Northern Cyprus chosen by convenience (accidental) sampling. The research employed a semi-structured interview form developed by researchers as data collection tool. According to the obtained results, it has been found that elementary school students encountered problems in topics related to the usage of social networks, computer viruses and relevant measures, and research processes on the internet.
\end{abstract}

Keywords - Internet, Technology, Elementary School Students

\section{$1 \quad$ Introduction}

\subsection{Definition of internet}

Internet and new communication technologies have had a very important structure in terms of the lives of individuals in our age. Children, young people or adults use the internet and new communication technologies intensively for different purposes in daily, educational and professional lives. According to Kaşıkcı et al. [1], the Internet is constantly in the process of development as the environment where users share their knowledge and views easily and quickly, and communicate with multiple users in 
different parts of the world. Information, research and expressions related to the internet which is promoted to being an essential living tool for themselves, covers a wide range in the literature.

According to its most well-known definition, internet is a wide network which ensures that users in the entire world can share information with each other. In a similar vein, Gürol and Sevindik [2] defined the internet as a network protocol which consists of millions of sub-networks and ensures that active users in these networks can interact with each other. Aydın [3] defined the internet as a wide global network on the basis of sharing information and stated that the internet has become a phenomenon which occupies an increasing space in the lives of people today. In addition to these definitions of internet usage, Pfoeffer [4] claimed that the internet today has become an important source of information for families, teachers and students alike.

Internet and its applications are used today for a variety of purposes by several users from different age groups depending on the wide usage ratio of computers and mobile devices. In the literature, several scientific studies and views are found concerning the usage purposes of internet.

\subsection{Usage purposes of internet}

It is known that the internet; one of the most important tools of information age serves several purposes from education to health, communication, marketing and economics [5]. In a similar vein, Inan [6] and Johnson [7] reported that the usage purposes of the internet which has a wide area of employment can be listed as communicating with all computers connected to computer network, ensuring instant mutual exchange of information, access to unlimited sources such as knowledge, articles, reports, books, conferences, announcements and registration procedures, access to data banks and their archives, access to library sources, shopping, travelling and flight reservations, several official application procedures, access to experts in different topics, and follow-up of news.

Development of technology and popularization of the internet has become effective in the adoption and application of innovations in several fields. Education is among the most important of these fields. Today, integration of the internet technologies in education settings has become an obligation as a requirement of the age that we are experiencing. Yigit et al. [8] stated that usage of internet technologies in education served several basic purposes such as rapid and easy access to information, communication and sharing.

Orhan and Akkoyunlu [9] indicated that the internet, which has become an important part of our lives, offered new opportunities and experiences to both children and families. In addition, they stated that the effective usage of the internet ensured individuals to reach any information in an easy and fast manner without any time and place restrictions, and share their activities with other users. Yalın [10] defined the internet as an important tool for the professional developments of teachers. In this respect, through the internet, teachers can share information with the experts of the field or their colleagues, access up-to-date resources using online libraries, have access to different teaching materials suitable for their course contents, obtain infor- 
mation on contemporary approaches concerning teaching strategies, methods and techniques, and structure their class activities based on the data they reach.

Madell and Muncer [11] and Berson and Berson [12] stated that users in different parts of the world use the internet for such purposes such as listening to music, doing research, sending e-mails, playing games, and making new friends. Gurol and Sevindik [2] stated that as a part of the social life today, the internet serves several purposes such as increasing the speed of communication between individuals, popularizing education services, and increasing quality and interaction.

In accordance with the scientific studies, an overview of the opinions displayed by a variety of researchers show that the internet serves several purposes for both institutions and individuals. This wide and popular style of usage presents several advantages to its users and brings to fore the question "how accurate and effective do we use internet?" as a research topic which needs examining. Presenting the problems that especially small age-group users experience in using internet and the type of approach they have to display in the face of these existing problems is extremely important in terms of creating a society with high level of awareness. In the literature, expressions and scientific studies displayed by different researchers can be found which examine the internet usage status of small-age users and the risk factors that await them.

\subsection{Possible risk factors in terms of small-aged internet users}

It is known that small-age group users perform several activities on an internet setting such as using social networks, browsing on the internet and chatting. Risk factors which await children that use the internet for different purposes are examined in different dimensions. Some of these dimensions are internet addiction, cyberbullying and sexual abuse of children.

Internet addiction: Internet addiction today is evaluated as one of the most important risk factors in terms of unconscious small-aged users. Having described the first diagnosis measures of internet addiction, Young stated that unnecessarily intense mental effort concerning the internet, excessive desire for the internet, spending more time than planned on the internet, and depending on excessive usage of internet, negative consequences on social life and lying to parents concerning the time spent online are indicators of internet addiction. Öztürk et al. [13] claimed that internet addiction is a type of addiction which can be witnessed at every age and stated that this type of addiction is most frequently seen in teenagers and children. Similar to this comment, Johannson and Götestam [14] reported that excessive use of social media applications negatively affected the social lives, physical and mental developments, and academic success of teenagers and led to the deterioration of their relations with their parents and peer groups.

Internet addiction appears as a concept which has been subject to several discussions and scientific studies for a long time; a compilation of the opinions and definitions in the literature show that there is consensus on the opinion that internet addiction, like other types of addiction, has negative effects on physical and mental developments, social lives, family and peer relations, academic success, professional de- 
velopment and work performance of individuals. In addition, it is a widely held opinion that internet addiction is a type of addiction which can be seen in every age group and that it is most frequently seen in children and teenagers who lack the conscious internet skills needed. In order to accept an individual as an" internet addict, some symptoms have to be observed in that individual. Chen et al. [15] reported that internet addicted individuals need to spend increasing time online, develop obsessed thoughts on internet usage, make excessive use of internet activities, neglect important social and professional requirements due to internet, and, despite being aware of the physical and mental problems that internet causes on them, continue excessive use of the internet. On the other hand, Young [16] explains the diagnosis criteria of internet addiction as follows:

- Excessive mental preoccupation with internet: Individuals wanting to spend time online continuously, making plans related to internet applications etc.

- Viewing internet as a need: Individuals accepting internet as a need just like food or water and feeling the need to use internet on an increasing basis.

- Psychological disorders in the case of lack of internet: When the individuals cannot have access to internet, they can show excessive nervousness, demoralization, overreaction.

- Spending more time online than planned: The individual spending more time on the internet activities than planned, and inability to restrain themselves from these activities.

- Problems in family, peer and work settings: Interfamily problems, unrest at work and loss of performance due to excessive use of the internet by the individual.

- The habit of lying: Observable especially in adolescents, lying to parents related to online activity and using online applications

- Seeing internet as an escape from experienced problems: The individual using the problems experienced in their lives as an excuse and seeing the internet as an escape route.

In the literature, in addition to the diagnosis criteria determined related to internet addiction, it is stated that there are some factors that led to the development of internet addiction. The leading factors which make individuals addicted to internet are sense of loneliness, easy and inexpensive access to internet, interesting aspects of internet for individuals, the freedom of expressing opinions and emotions without revealing true identity, the effort to meet socialization needs in internet settings, and lack of control mechanism in online settings [17-18-19].

Cyberbullying: Cyberbullying is accepted as one of the most important risk factors for internet users. Belsey [20] defined cyberbullying an intentional and repetitive type of bullying which is exerted by an individual or a group using information and communication technologies and for the purpose of giving harm to other people from different aspects. In a similar vein, cyberbullying is the evil mixture of other forms of sociality and using wicked and negative discourses to other people using information and communication technologies, especially internet [21]. Li et al. [22] and Nocentici et al. [23] state that cyberbullying includes harmful digital actions towards other individuals and represents an intentional and repetitive type of bullying. The literature 
provides leading features of cyberbullying. Shariff [24] explains these features as follows:

- In online settings, individuals can display bullying by hiding their true identity.

- The situation of individuals who are the victims of cyberbullying in online settings is becoming widespread rapidly and reaching a wider mass through different online settings.

- Cyberbullying actions which can be observed in online settings can include sexual contents more easily and readily compared to normal settings.

Sexual abuse directed towards children: Sexual abuse directed towards children is defined as children who are under the age of consent being active in the sexual satisfaction of an adult or the negligence of this situation [25]. In a similar expression, Olive [26] described child sexual abuse as the sexual activity between an adult and a child who is under the age of consent. Semerci [27] stated that one of the most serious risk factors in terms of children in internet settings is child pornography and that people defined as pedophiles frequently attending chat rooms used by children and try to communicate with them. Valcke et al. [28] stated that one of the most serious internetrelated risk factors for children was the ease of access to pornographic content. Similarly, Celen et al. [29] suggested that the ease of access by children to illegal and sexual web sites on the internet poses an essential threat for children.

Based on the explained aspects, internet usage offers several advantages to the users but it also can become an essential source of threat for younger and unaware users. Based on this fact, displaying the problems experienced by younger age groups using internet bears huge importance in terms of cultivating individuals who can use the internet consciously, accurately and effectively. In the light of this information and reasons, the objective of this study is to determine the problems experienced by 5 thgrade elementary school students during internet usage. In order to realize this goal, answers were sought to the following questions:

- What are the problems experienced by 5 th grade elementary school students in social networks?

- What are the problems experienced by 5 th grade elementary school students in terms of computer viruses and related measures?

- What are the problems experienced by 5th grade elementary school students in terms of making research and obtaining information on the internet?

\section{$2 \quad$ Method}

Most of the styles are intuitive. However, we invite you to read carefully the brief description below. 


\subsection{Research model}

In this study which was conducted with the purpose of determining the problems experienced by 5 thgrade elementary school students in internet usage, interview method, which is a quantitative method, was used. Quantitative study aims at examining any subject in depth and detail. The most frequently used quantitative method is interview. Interview is considerably strong in terms of revealing the data, opinions, experiences and emotions of individuals [30].

\subsection{Sample group}

The sample group of the study which was conducted at a private elementary school under the Ministry of Education of Northern Cyprus consists of 103 elementary school 5th grade students who were chosen with convenience (accidental) sampling method. Demographic data as regards the sample group are provided in detail in Tables 1 to 5 .

Table 1. Distribution of students concerning gender, grade and nationality factors

\begin{tabular}{|c|c|}
\hline Sex & f \\
\hline Female & 61 \\
\hline Male & 42 \\
\hline Nationali & \\
\hline North Cyprus & 67 \\
\hline Turkey & 28 \\
\hline Other & 8 \\
\hline Total & 103 \\
\hline
\end{tabular}

Among the students who constituted the study group of the research, 61 were females and 42 were males. 67 of these students were Northern Cyprus nationals, 28 were Turkish nationals, and 8 were nationals of England, Russia, Iran and Kazakhstan.

Table 2. Distribution of computer, tablet, smart phone ownership and internet connection status of elementary school students

\begin{tabular}{|l|c|c|}
\hline & Yes & No \\
\hline Desktop Computer / Laptop & 87 & 16 \\
\hline Tablet PC & 101 & 2 \\
\hline Smart Phone & 94 & 8 \\
\hline Internet Connection & 103 & \\
\hline
\end{tabular}

According to the data in Table 2, all of the elementary school students who constitute the sample group have internet connection at their homes. In addition, it can be seen that the students mostly have tablets and smart phones in the general ratio. This datum shows that new communication technologies are widely used by children at small ages as well. 
Table 3. Distribution of elementary school students as regards time spend on internet

\begin{tabular}{|l|c|}
\hline \multicolumn{1}{|c|}{ Time } & f \\
\hline Less than 1 hour & 18 \\
\hline $1-2$ hours & 23 \\
\hline $2-3$ hours & 39 \\
\hline 3-4 hours & 18 \\
\hline $4-5$ hours & 4 \\
\hline $5-6$ hours & 1 \\
\hline
\end{tabular}

According to the data in Table 3, it can be seen that the elementary school students covered by the study mostly use internet for 2 to 3 hours.

Table 4. Distribution of elementary school students as regards social networking sites they use

\begin{tabular}{|l|c|}
\hline \multicolumn{1}{|c|}{ Social Network } & f \\
\hline Facebook & 98 \\
\hline Instagram & 45 \\
\hline None & 5 \\
\hline
\end{tabular}

According to the data provided in Table 4, the majority of the elementary school students covered by the study use Facebook. It is seen that only 5 students are not members of any social networking sites. This datum shows that despite the age limits for being a member of the relevant social networking sites, children at small ages intensely and effectively use social networking sites.

Table 5. Distribution of elementary school students as regards purpose of using Internet

\begin{tabular}{|l|c|}
\hline \multicolumn{1}{|c|}{ Aim of Using Internet } & f \\
\hline Play game & 99 \\
\hline Watch movie & 87 \\
\hline Listening music & 45 \\
\hline Use social network & 98 \\
\hline Research and information & 71 \\
\hline Chat & 75 \\
\hline Studying & 52 \\
\hline
\end{tabular}

According to the data in Table 5, it can be seen that elementary school students covered by the study mostly use the internet to spend time on social networking sites, playing games and watching videos. This datum reveals that children usually use internet and new communication technologies for entertainment purposes.

\subsection{Data collection tools}

In the study, semi-structured interview form was used by the researchers with the purpose of determining the problems experienced by elementary school students while using internet. A Literature search was conducted first at the stage of developing the relevant interview form. Then, 20 randomly selected elementary school stu- 
dents were asked to write an essay on the general problems they experienced while using the internet. The data obtained from the literature search and the essays written by students were evaluated using content analysis method and it was decided that interview form should consist of four distinct sections according to the obtained data. These sections would be as follows:

- Personal information

- Usage of social networks and experienced problems

- Problems concerning the measures against computer viruses and malwares

- Problems concerning doing research and obtaining information on the internet

In order to check the structure and outlook validation of the draft interview form, the opinions of 17 experts from the field were sought. In lien with the obtained opinions, necessary corrections were made and the interview form was updated for application.

\subsection{Application}

Collection of research data was performed in the spring semester of the 2018-2019 academic year in a period of 1 month. In the first stage of application dimension, after receiving necessary permissions, relevant classrooms were visited and interviews which almost took 10 minutes were conducted with each student. In order to prevent loss of data, the interviews were recorded after receiving permission from the school management and parents of students.

\subsection{Analysis of data}

"Coding according to the concepts obtained from data" was used as a technique in the qualitative data obtained from the study. Researchers and an academician who is specialist in the field coded data separately and then conducted a comparison. In the study, the answers obtained from the answers of the students were coded separately and brought together within certain concepts. In the next stage, the frequencies of these codes were presented in tables for convenience purposes for the students. The identities of 103 students who were interviewed were kept confidential and each was given an individual number (First student: S1, second student: S2).

\section{$3 \quad$ Findings}

The objective of this study is to determine the problems experienced by students in internet usage. In accordance with this general objective and sub-objectives, the obtained research findings were evaluated under three main headings namely the general problems experienced by elementary school students in social network sites, problems experienced related to computer viruses and relevant measures, and problems experienced in the process of doing research and obtaining information on the internet. 


\subsection{Problems experienced by elementary school students in social network} sites

Table 6 gives the problems experienced by elementary school students on social network sites in detail.

Table 6. Problems experienced by elementary school students in social network sites

\begin{tabular}{|l|c|}
\hline \multicolumn{1}{|c|}{ Theme } & f \\
\hline Making privacy settings in social networking sites & 67 \\
\hline Encountering detrimental users in social networking sites & 23 \\
\hline Taking measures against hacking threats in social networking sites & 55 \\
\hline The time spend in social networking sites leading to negligence of daily responsibilities & 71 \\
\hline Being exposed to malignant contents shared by others in social networking sites & 35 \\
\hline Intervening in case of a technical problem in social networking sites & 11 \\
\hline
\end{tabular}

According to the data in Table 6, it can be seen that elementary school students who use social networking sites experience several problems as regards to these settings. According to the opinions presented, an important majority of students have problems concerning the privacy settings on the social networking sites they use and suffer from a lack of knowledge in this regard. The opinions of some of the interviewed students are presented below.

"I use Facebook but I do not exactly know how to make my information, photographs and posts on Facebook private. I am having problems in this issue." S18

"I do not feel comfortable about people other than my friends list seeing my photographs and posts on Facebook. But I do not know how I can make sure that they can only be seen by my friends. " $S 71$

As shown by the comments, students suffer from lack of knowledge as regards to privacy and security settings in Facebook and other social networking sites. In this context, students do not feel safe on social networking sites and are exposed to a number of risk factors. Likewise, interviewee students stated that they experienced problems such as being exposed to dangerous users who can endanger the safety of other users.

"One day when I was talking to a friend on Facebook, a man who I did not know sent a message like "how are you". I did not know what to do; I told my mum and she blocked that man.” $S 23$

"On Facebook sometimes people I do not know send me friendship requests. My family does not allow me to add to my list people I do not know. And I do not accept their requests." S4 
According to student opinions, they do not know how to take action against the problem of being "hacked" which is a common problem in social networks. The opinions of some of the interviewed students are presented below.

"One day my sister told me that her Facebook was hacked. I asked what being hacked was, and she answered that it meant that your Facebook account is stolen by other people. That day I feared that my Facebook could be stolen too, but I did not know what to do in order to prevent it." S3I

"Last year my Facebook account was hacked. My friend said that some people were sending messages to other people and asking for their credit card numbers in order to give gift cards. I could not retrieve my Facebook, as I did not know how to retrieve it so we created a new Facebook account." S45

According to these opinions, a majority of the students confess that spending too much time on social networking sites leads to negligence of daily responsibilities such as doing homework.

"I enjoy spending time on Facebook too much but sometimes I realize that it has a negative impact on my courses. Especially when playing a Facebook game, I lose my sense of time." 567

"Sometimes I spend too much time on Facebook. Mom gets mad at me and says that I behave irresponsibly towards my courses." S39

"On a weekend, after having my breakfast, I began spending time on Facebook on my tablet. There were homework assignments for the next day. But I spent so much time on Facebook that it became too late. The next day I had to go to school without doing my homework assignments." S5

As can be understood from the comments, students are aware that when they spend too much time on social networks such as Facebook, they neglect their responsibilities that they have to perform on a daily basis including doing their homework. However, they act unconsciously as regards to what is needed to solve this problem.

Likewise, the opinions reveal that students become the victims of inappropriate content shared by other people in social networks.

"Once, someone in my friends list shared a video about the children dying in Syria. I was very adversely affected when the video appeared instantly and I could not sleep at night". S12

"Sometimes things about which I feel very uncomfortable are shared in Facebook. I feel very bad when I see them." S89 
"Some infected posts are posted on Facebook. When I click that link my computer or tablet is also infected with viruses. For this reason, I sometimes have problems." S101

According to the obtained opinions, it is seen that students are not knowledgeable as to how they will intervene in case of a problem when they face one on social networks and how they will seek for solutions. The opinions of some of the interviewed students are presented below.

"One day in the previous months, I forgot my password when I was to enter Facebook. No matter how hard I tried, I could not remember the password. I did not know how to enter my account. I had to open a new Facebook." S41

A general evaluation reveals that elementary school students experience problems in such issues as managing privacy settings in social networking sites, taking measures against the capturing of their accounts by ill-intentioned users, and how to act in the face of a problem, all of which are related to application. In addition, it can be seen that a majority of the students covered by the study encounter such problems as neglecting their daily responsibilities, i.e. studying their lessons and doing their homework, in case of spending too much time on social networking sites, and encountering ill-intentioned users.

\subsection{Problems experienced by elementary school students related to computer viruses and relevant measures}

Table 7 gives in detail the problems experienced by elementary school students in social networking sites.

Table 7. Problems experienced by elementary school students concerning computer viruses and relevant measures

\begin{tabular}{|l|c|}
\hline \multicolumn{1}{|c|}{ Theme } & f \\
\hline Taking measures against computer viruses & 99 \\
\hline Activating the anti-virus program on the computer & 76 \\
\hline Performing virus scan before using storing devices such as flash discs & 91 \\
\hline
\end{tabular}

According to the data included in Table 7, it is seen that students are experiencing problems concerning computer viruses and relevant measures. It is observed that students are particularly experiencing issues related to lack of knowledge as to which measures, they should take against computer viruses. Some example opinions are provided below.

"I do not know what I will do when a virus infects my computer or tablet. I usually ask for help from someone who does." S28 
"In the previous months a virus infected my tablet due to a game I downloaded on my tablet. I was extremely worried but I did not know what to do. I waited for dad to come home so he could solve the problem." S91

According to the obtained opinions, elementary school students are having problems due to lack of knowledge as regards to performing a virus scan before using storage devices such as flash discs.

"I know that viruses can infect my computer through flash discs but I do not know how to perform a virus scan on these discs." S78

"The flash disc I used at school was infected with viruses before. When I attached it to my computer, a warning for viruses emerged. When I asked dad, he said that my flash disc was infected with virus and that I had to perform a virus scan and delete the viruses. But I asked for his help as I did not know how to do it." S91

According to the opinions obtained, it has been found out that students experience problems concerning using virus programs actively on their devices such as computer, tablet and phone. It has been determined that a majority of the students do not have any information about using a virus program.

"I have a virus program on my tablet. But I do not know how to use it." S33

"The shop where we bought the computer had downloaded a virus program. But I do not use it as I do not know how to use it!" S3

\subsection{Problems experienced by elementary school students related to computer viruses and relevant measures}

Table 8 gives in detail the problems experienced by elementary school students in the process of doing research and obtaining information on the internet.

Table 8. Problems experienced by elementary school students in the process of doing research and obtaining information on the internet

\begin{tabular}{|l|c|}
\hline \multicolumn{1}{|c|}{ Basic opinions } & S \\
\hline Being sure that the information on the internet are reliable and accurate & 96 \\
\hline Determining appropriate keywords when doing research on a topic on the Internet & 24 \\
\hline Ads appearing on the internet while doing a research & 34 \\
\hline
\end{tabular}

Today, one of the most important objectives of internet usage is doing research and obtaining information. Elementary school students make use of the opportunities provided by the internet and try to do research and obtain information about the topics they feel interested or the contents of their courses. On the other hand, it is observed that elementary school students are experiencing some problems while doing research on the internet. According to the obtained opinions, one of the most important prob- 
lems experienced by students while doing research on the internet is that they are not sure about the reliability and accuracy of the information on internet sites.

"When our teacher gives a research homework, I usually look it up on the internet. But I am having difficulty in deciding whether the information on the internet sites is accurate or not." S5

"One day our teacher gave a research homework in Social Sciences course. I prepared my homework by researching online. When I went to school the next day, my teacher told me that the information was not true. Form that day on, I do not trust every information and news on the internet." S103

The comments make it clear that a majority of students are having problems concerning the reliability of the information found on the internet and cannot decide which information is true and which information is false. Likewise, when the opinions are examined, it can be seen that elementary school students are annoyed by the ads that appear while doing research on the internet and perceive it as a problem.

"Internet is like a treasure where we can reach all information instantly but the ads which appear suddenly on the internet site are annoying!" S55

"The introductory messages and visuals that appear on the screen while doing research prevent me from reaching information on the site." S79

"The ads and messages which suddenly appear on websites while doing research are so annoying! Sometimes I cannot see the information I need because of them. I do not know how I can prevent them from appearing. "S71

According to these opinions, another problem experienced by students while doing research on the internet is determining appropriate keywords on search engines. Students are experiencing indecisiveness as to which keywords they would choose while doing a research on the internet about a topic.

"I cannot be sure which words I should write on Google while doing research on a topic on the internet as sometimes things which are irrelevant to the word I write are brought." S13

\section{Conclusion, Discussion and Recommendations}

This research was carried out to determine the problems experienced by elementary school $5^{\text {th }}$ grade students about internet usage. Some conclusions have been reached in line with this general purpose and the sub-objectives. It has been found out that elementary school students are experiencing problems on social networking sites concerning taking measures against the capturing of their accounts by other users and 
intervening in case of a technical problem which are related to application. In addition, it has been determined that the students covered by the study group are having problems on social networking sites related to being exposed to negative contents or virus elements shared by other users and neglecting their daily responsibilities due to spending excessive time on social networking sites. It is known that membership to social networking sites which are used today is banned for children below a certain age. Despite this rule and age limit, children at small ages can be members of social networking sites and perform some activities there which can lay the grounds of facing several issues and threats. For this reason, parents and teachers alike have important responsibilities as to develop accurate internet usage awareness in children and protect them from possible dangers on social networking sites. For this effect, seminars, conferences and similar activities on "accurate, safe and effective use of internet" can be organized which target teachers and parents which would contribute to the formation and popularization of this awareness in the society. On the other hand, broadcasts on the local television channels of countries or cities can be effective in the development of such awareness in the society.

According to another result of the study, elementary school 5 th graders have a high level of awareness concerning the damages led by viruses on computers, tablets and mobile devices. However, despite this high level of awareness, it has been found out that students are experiencing problems in application dimension such as taking measures against computer viruses, activating anti-virus programs, and performing virus scan before using storage devices such as flash discs. This finding reveals that education is a necessity for such students in terms of taking measures against computer viruses and effectively using anti-virus programs. In this context, including in the curricula of informatics courses activities at application level in terms of computer viruses and measures that can be taken against these viruses can make contribution in terms of meeting the need for such education.

It has been found out that another result of the study is related to the problems experienced by elementary school students in terms of using internet for researching and information-gathering purposes. It is clear that a majority of elementary school students are experiencing problems in terms of being sure of the accuracy of the information on the internet, using search engines effectively, choosing appropriate keywords, and advertisements that appear on the screen while doing research. For this reason, it is essential to ensure that the internet, which has become the most important source of information today, is effectively used by elementary school students for research and information-gathering purposes. For this effect, including relevant activities in the curricula of informatics courses at elementary school stage can be effective in terms of meeting the need of students for this kind of education.

This research examined only the elementary school level. It can be recommended that similar studies in the future should investigate the secondary school level so that the problems experienced by students who continue their education at the relevant education level can be evaluated. 


\section{$5 \quad$ References}

[1]Kaşıkcı, D.N., Çağıltay, K., Karakuş, T., Kurşun, E., Ogan, C. (2014). Internet Habits and Safe Internet Use of Children in Turkey and Europe. Education and Science, 39(172), 230-243.

[2] Gurol, M., Sevindik, T. (2001). Fırat Üniversitesi Öğretim Elemanlarının İnternet Kullanım Düzeyleri ve Görüşlerinin Belirlenmesi. Eğitim Fakültesi Dergisi, 3, 283-290. https://doi.org/10.19171/uuefd.49420

[3] Aydin, I. (2013). Children, Internet and Ethics. Gençlik Araştırmaları Dergisi, 1(2), $97-$ 119.

[4] Pfoeffer, P. (2002). Web Usability and Children: Current Research and Implication for Information Professinals. Orana. 38(2), 11.

[5] Kuzu, A. (2011). İnternet ve Aile. Aile ve Toplum, 7(27), 9-32.

[6] Inan, A. (2010). İlköğretim II. Kademe ve Ortaöğretim Öğrencilerinde İnternet Bağımlılığı. Yüksek Lisans Tezi, Atatürk Üniversitesi, Sosyal Bilimler Enstitüsü, Erzurum. https://doi.org/10.24106/kefdergi.2559

[7] Johnson, G.M., (2010). Young Children's Internet Use at Home and School: Patterns and Profiles, Journal of Early Childhood Research, 8(3), 282-293. https://doi.org/10.1177/ $1476718 \times 10379783$

[8] Yiğit, T., Sigla, M., Aksungur, M., Erbağ, S., Palaz, U. (2007). Çocuklar İçin İnternet Güvenliği: Bir Ebeveyn Kontrol Aracı. Akademik Bilişim'07 - IX. Akademik Bilişim Konferansı Bildirileri, Dumlupınar Üniversitesi, Kütahya.

[9] Orhan, F., Odabaşı, F. (2004). İlköğretim Öğrencilerinin İnternet Kullanımları Üzerine Bir Araştırma. Hacettepe Üniversitesi Eğitim Fakültesi Dergisi, 26, 107-116. https://doi. org/10.17556/erziefd.447614

[10] Yalın, A. (2001). Çocuklar ve İnternet. Bilişim Toplumuna Giderken Psikoloji, Sosyoloji ve Hukuka Etkiler Sempozyumu.

[11] Madell, D., Muncer, S. (2004). Gender differences in the use of the internet by English secondary school children. Social Psychology of Education, 7, 229-251. https://doi.org/ 10.1023/b:spoe.0000018552.85903.4d

[12] Berson, I., \& Berson, M. (2003). Digital literacy for effective citizenship. Social Education, 67(3), 164-167.

[13] Öztürk, O., Odabaşıŏlu, G., Eraslan, D., Genç, Y., Kalyoncu, O. A. (2007). İnternet Bağımlılığı: Kliniği ve Tedavisi, Bă̆ımlılık Dergisi, 8(1), 36-41.

[14] Johansson, A., Götestam, K.G. (2004). Internet Addiction: Characteristics of a questionnaire and prevalence in Norwegian youth (12-18 years). Scand J Psychol, 45(1), 223229. https://doi.org/10.1111/j.1467-9450.2004.00398.x

[15] Chen, K., Tarn, M.J., Han, B.T., (2004). Internet Dependency: It's Impact on Online Behavioral Patterns in E-commerce. Human Systems Management, 23 (1), 49-58.

[16] Young, K.S. (1996). İnternet Addiction: The Emergence of a New Clinical Disorder. Cyber Psychology and Behavior, 1 (3), 237-244.

[17] Inan, A. (2010). İlköğretim II. Kademe ve Ortaöğretim Öğrencilerinde İnternet Bağımlılığı. Yüksek Lisans Tezi, Atatürk Üniversitesi, Sosyal Bilimler Enstitüsü, Erzurum. https://doi.org/10.24106/kefdergi.2559

[18] Bayraktutan, F. (2005). Aile İçi İlişkiler Açısından İnternet Kullanımı. Yüksek lisans tezi, İstanbul Üniversitesi, Sosyal Bilimler Enstitüsü, İstanbul.

[19] Henderson, E. C. (2001). Understanding Addiction. University Pres of Mississippi. 4(1), 153-167. 
[20] Belsey, B. (2006). Cyberbullying: An emerging threat to the "Always On" generation. Retrieved from www.cyberbullying.org.

[21] Canberk, G., Sağıroğlu, S. (2007). Çocuklar ve Gençlerin Bilgisayar ve İnternet Güvenliği, Politeknik Dergisi, 10(1), 33-39.

[22] Li, Q., Cross, D., Smith, P.K. (2012). Cyberbullying in the Global Playground. West Sussex: Blackwell Publishing.

[23] Nocentini, A., Calmaestra, J., Schultze-Krumbholz, A., Scheithauer, H., Ortega, R., Menesini, E. (2010). Cyberbullying: Labels, Behaviours and Definition in Three European Countries. Australian Journal of Guidance and Counselling, 20(2), 129-142. https://doi. org/10.1375/ajgc.20.2.129

[24] Shariff, S. (2005) Cyber-Dilemmas in the New Millennium: Balancing Free Expression and Student Safety in Cyber-Space. Special Issue: Schools and Courts: Competing Rights in the New Millennium. McGill Journal of Education. 40(3), 467-487.

[25] Johnson, G.M., (2010). Young Children's Internet Use at Home and School: Patterns and Profiles, Journal of Early Childhood Research, 8(3), 282-293. https://doi.org/10.1177/ $\underline{1476718 \times 10379783}$

[26] Olive, M.F., Collins, C., Levitt, P. (2007). Child Abuse and Stress Disorders. New York: Infobase Publishing.

[27] Semerci, B. (2006). Hukuki ve Kronolojik Açıdan Çocuk Pornografisi Paneli. Retrieved from www.hukukinet.org.

[28] Valcke, M., Bonte, S., De Wever, B., Rots, I. (2010). Internet parenting styles and the impact on Internet use of primary school children. Computers \& Education, 55(2), 454464. https://doi.org/10.1016/j.compedu.2010.02.009

[29] Celen, F.K., Celik, A., Seferoğlu, S. (2011). Çocukların İnternet Kullanımları ve Onları Bekleyen Çevrim-İçi Riskler. XIII. Akademik Bilişim Konferansı Bildirileri, 2 - 4 Şubat 2011, İnönü Üniversitesi, Malatya.

[30] Yıldırım, A., Şimşek, H. (2005). Sosyal Bilimlerde Nitel Araştırma Yöntemleri. Ankara: Seçkin Yayınevi.

\section{Authors}

Aykut Yasakcı is a lecturer and $\mathrm{PhD}$ student in Near East University. He studies $\mathrm{PhD}$ in Computer Education and Instructional Technology. His current research interests focus on educational technology.

Hasan Özdal works in Final International University as a lecturer. Also he is member of Cyprus Educational Sciences Association. He studied PhD in Computer Education and Instructional Technology. His current research interests focus on educational technology and graphic design in education.

Article submitted 2019-09-23. Resubmitted 2019-10-23. Final acceptance 2019-10-25. Final version published as submitted by the authors. 